\title{
PSA Level Greater than or Equal to Fifteen
}

National Cancer Institute

\section{Source}

National Cancer Institute. PSA Level Greater than or Equal to Fifteen. NCI Thesaurus.

Code C153416.

A blood concentration of prostate specific antigen greater than or equal to $15 \mathrm{ng} / \mathrm{mL}$. 